\title{
The Effects of Foot and Mouth Disease in Yak and Cattle herds of Rasuwa District due to Climate Change
}

\author{
Deepak Dorje Tamang \\ Department of Biotechnology, Nepal.
}

Corresponding author: Deepak Dorje Tamang, Department of Biotechnology, Nepal.

Received date: July 31, 2021; Accepted date: September 28, 2021; Published date: October 09, 2021

Citation: Deepak Dorje Tamang (2021) The Effects of Foot and Mouth Disease in Yak and Cattle herds of Rasuwa District due to Climate Change. J, Biotechnology and Bioprocessing; 2(8); DOI: 10.31579/2766-2314/051

Copyright: (C) 2021, Deepak Dorje Tamang, This is an open access article distributed under the Creative Commons Attribution License, which permits unrestricted use, distribution, and reproduction in any medium, provided the original work is properly cited.

\begin{abstract}
In the era of Climate Change, the paper spotlights the importance of managing the high-altitude range land management in Nepal's northern Rasuwa district bordering the Tibetan plateau. It points to the important fact that policies and strategies need to be inclusive and intersectional with gender equality and social inclusion (GESI) as a vital principle of good governance. Such policies, inclusive governance and support to vulnerable transhumance herders will enhance adequate grass and fodder for yak, chauri, sheep and cattle and at the same time provide veterinary support leading to improved livelihoods for the entire communities. Yak herding is carried out by Tamang transhumance community and in the age of climate change; pasture management together with extension support from local government, is critical to provide additional income to the local communities. The paper examines risk factor, i.e., foot and mouth disease (FMD) and vital nutrient requirements in terms of good quality grass fodder. It also examines the role of customary headman called the "Chogo" who collectively with his "local counsel" facilitate, wise use of the region's natural resources, i.e., water, irrigation, forest, agriculture and above all pasture land and mediates local conflicts.

Keywords: climate change, customary law, rangeland management, traditional headmen, transhumance, grass fodder, governance, traditional institution, equity, gender equality, social inclusion, livelihoods
\end{abstract}

\section{Introduction}

Socio-culturally constructed gender roles and responsibilities not only shape women and men's differential access, ownership and control over resources but also influence their capacities and capabilities to adapt to climate change (Skinner, 2011). Women's and socially marginalized community members vulnerability to climate change related hazards are different from that of general milieu to a great degree (Neumayer and Plümper, 2007). During external shocks and disasters resulting in widespread droughts, floods or landslides; more women and socially marginalized community members either suffer greatly or die due to of lack of early information, timely communication, mobility, correct decision-making, access to resources, capacity building training, genderbiased cultural norms and barriers (Nellemann, Verma and Hislop, 2011).

However, dominant climate change adaptation approaches and methodologies tend to be gender and social inclusion (GESI) blind, as biophysical and economic determinants receive greater weight (Nightingale, 2009). Climate change adaptation and mitigation policies, climate governance and practices in the highland Himalayan communities and regions are greatly under-researched. This leads to inadequate understanding of climatic and non-climatic drivers of change in the region including better understanding of gender roles and relations at the household and community level when it comes to coping strategies.
In order to contribute to filling these gaps in knowledge, and to understand gender and social vulnerabilities in climate change context; a number of key questions related to livelihood challenges and inclusion are important in the context of climate change and transhumance herders of northern Rasuwa. These are inter alia:

- What are some of the risk factors, i.e., livestock related diseases that create vulnerability to human population in terms of health and livelihoods vulnerabilities?

- What are the inclusion differentiated impacts of climate induced hazards and shocks in the highland Himalayan communities? And modes of autonomous adaptation and engagement with institutions to ensure livelihoods and employment?

- How these are disadvantaged community members coping in terms of household leveldivision of labour, decision-making plus access to and control over key resources including livestock population?

- What are the Gender Equality and Social Inclusion (GESI) What are gender and socially disaggregated access, control and ownership of common property, i.e., rangeland that impact their 
livelihoods in response to climate and other drivers of change such as globalization or infrastructure development?

\section{Conceptual framework}

Definitions of vulnerability in climate change stemmed from the study of natural hazards in which vulnerability was perceived as biophysically induced outcome of external hazardous events. This was dominant until the 1980s, when social scientists utilised biophysical definitions of vulnerability (Adger, 1999; Hewitt, 1983). Starting with Wisner (1978) and Hewitt (1983), a shift began and there was a growing recognition that impacts of hazardous events, even within small geographic areas, are not homogenous. And that it is not just the biophysical characteristics of an event that determine vulnerability, rather social structures play important roles. Social vulnerability with pre-existing internal conditions and structures of a society, which are unequal results in "the differential capacity of groups and individuals to deal with hazards" (Dow, 1992; Gerlitz et al., 2014; Hewitt, 1983) and has differentiated impacts of a hazard on a population.

An important facet of vulnerability is gender and social inclusion (GESI) and the recognition that men and women experience climatic change and associated hazard events differently (Aguilar, 2009; Alston, 2014; Brody, Demetriades and Esplen, 2008; Lambrou and Laub, 2004; Lambrou and Piana, 2006; Terry, 2009). An emerging body of material, much of it from the gender and disaster literature, provides abundant empirical evidence of the myriad ways in crisis situations suggesting that effects of changes are not gender neutral and that women and girls tend to be more vulnerable to hazard events, compared to even the men of particular location or category of the same society.

Recognition of heterogeneity - within male, female plus "socioeconomic" intersections - is important. It is crucial to recognize that GESI "intersects" with other axes of social differences, such as ethnicity, age, class, caste, etc.; resulting in a mutually constitutive identity (Barager, 2009; Motzafi-Haller and Abu-Rabia-Queder, 2009; YuvalDavis, 2006). It is, therefore, the specific combinations of these "intersecting" axes of social differences that shape "social" and "gendered" positions as lived experiences and thus affect vulnerability" (Osborne, 2015:131).

This case study recognizes the complexity of these socio-economic and civic or institutional factors. These are market forces, consumerism, urbanization, globalization, infrastructure development and technological intervention in a place and time. This is further related to internal geopolitical and socio-economic factors of social structure, gender structure, geography, political economy and decision making processes and institutions. They combine to alter or influence the livelihood options of women and men, determining the capability to respond to risk posed by climatic and socioeconomic stressors.

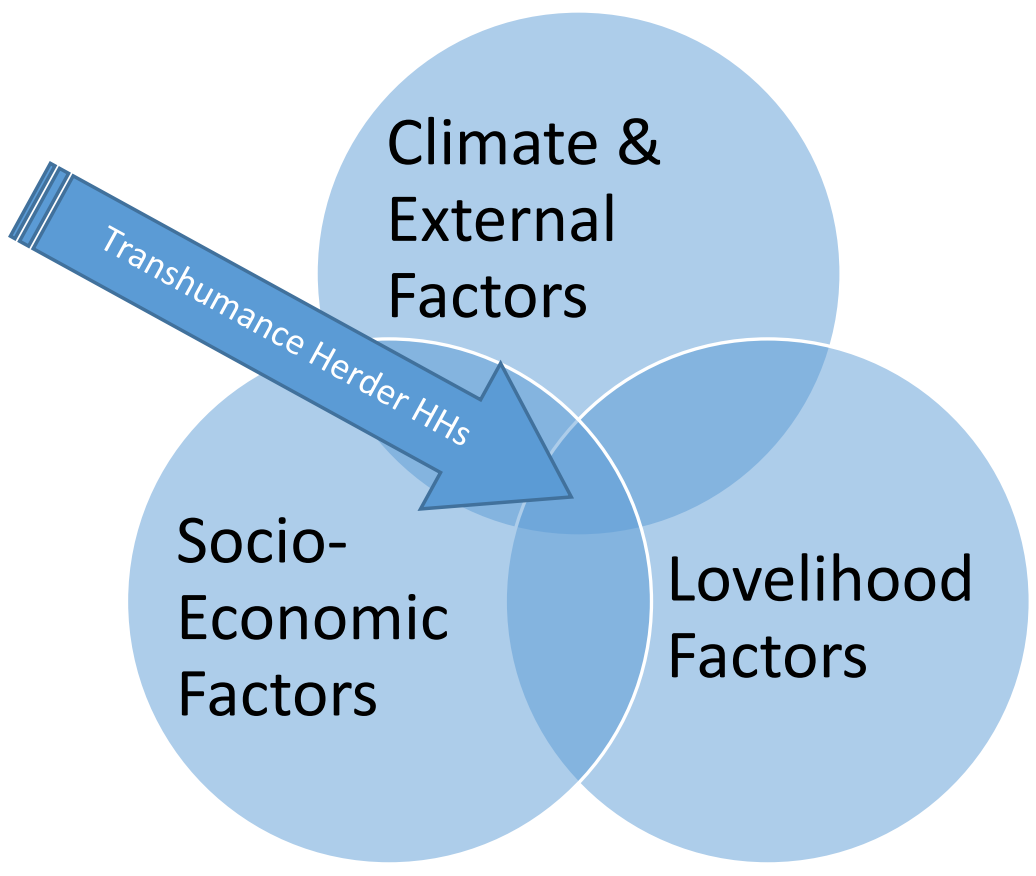

Figure 1. Transhumance Herders Coping Strategy

The Climate Change and its effect in Transhumance community

Gandaki river basin originating from northern Himalaya with its seven main tributaries is glacier fed river system originating from Himalaya. It originates in Tibet flows through Nepal and drains out at plains of Bihar, India joining the river Ganga. Of the seven main tributaries, two originates in Nepal and the rest in Tibet. The case study area is located along one of its tributaries, called Trishuli located in Rasuwa, Nepal. The Figure 2 below shows the specific locations of the transhumance herders' hamlets in Rasuwa District. Today, they fall under Ama Chidingmo (Parvati Kunda) rural municipality. 


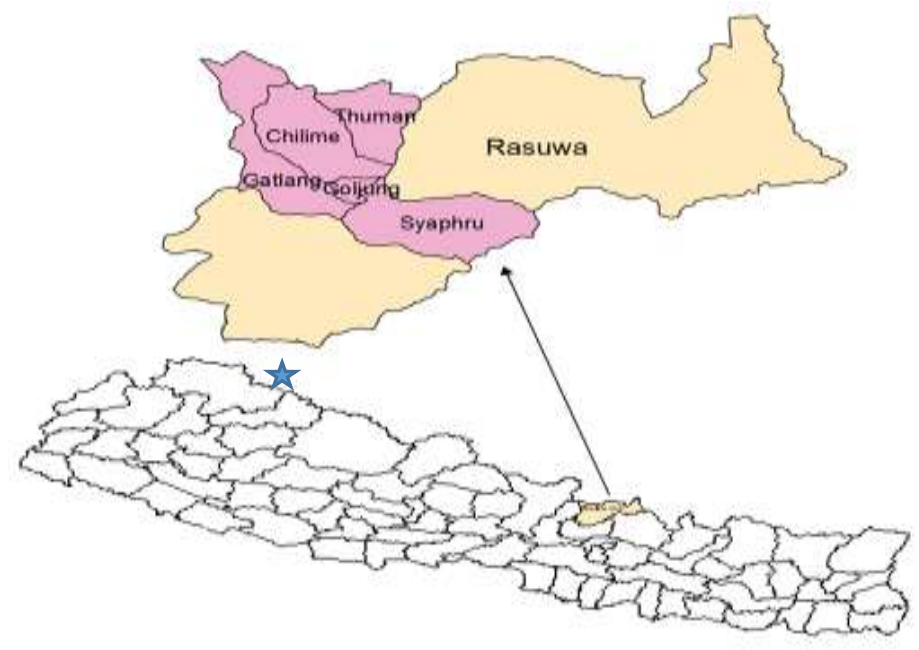

Figure 2: Case Study Sites in Rasuwa District, Nepal

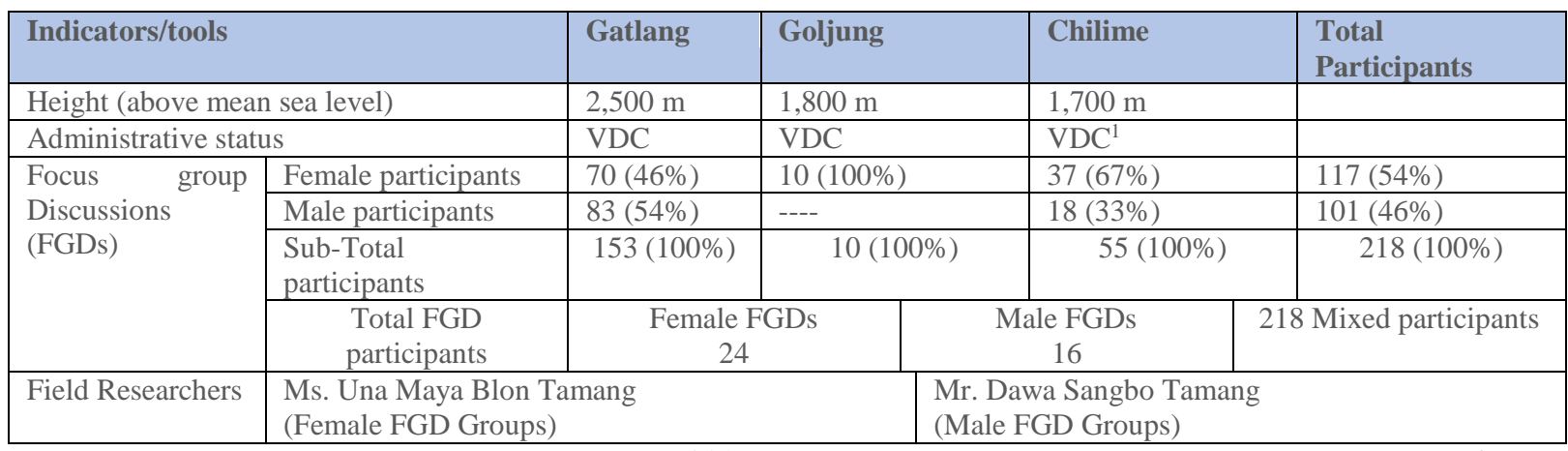

(Source: Focus Group Discussions (FGDs), June 2017 in Upstream Rasuwa, HI-AWARE ICIMOD/SEARCH Nepal)

Table 1: Case Study hamlets with focus group discussions (FGDs)

\section{Lives and livelihoods of the Transhumance Herders}

Based on a robust number of 40 FGDs and responses from 218 respondents plus a number of qualitative and quantative data based on a basket of PRA tools (participatory rural appraisal) such as KIP (key informant persons) and secondary district data; this section narrates the presence of a number of challenges. These are prominently the Foot and Mouth Deasese (FGDs) in yak and other ruminant livestock, affecting livelihoods and coping strategies, including gender roles and responsibilities. These data reveals different gender and social consequences for various groups in the study area. It focuses on one dominant aspect of the community livelihoods activity, i.e., transhumance herding. The "inter-sectional" differentiations in highland Rasuwa are multifarious, hinging, inter alia on geography, economy, socio-cultural, material, physical, institutional and political elements. The altitudes vary from 2,200m above mean sea level in Gatlang to $1,800 \mathrm{~m}$ in Goljung and $1,700 \mathrm{~m}$ in Thambuchet/Chilime ${ }^{2}$. In terms of "aspect", these hamlets vary considerably as well being either on the "windward" or "leeward" side of the mountain ${ }^{3}$. These hamlets, thus, face north-west, north or south-east directions. These "aspects" have considerable influence in the local

1 According to the New Constitution of Nepal 2015, the new "Political-Administrative" boundaries of the country have been reconstituted internally. Village Development Committees (VDCs) have been restructured under the New Constitution, 2015. The Federal System in Nepal now has 1 Federal, 7 Provincial and 753 Local Governments. VDCs have been aggregated and subsumed into Rural Municipalities (Goan Palika) or Local Governments (LG). The former VDCs currently form more or less the new Ward of the Rural Municipalities. There are currently 753 LGs disaggregated into 6 metropolitan (ma-hanagar); 11 sub-metropolitan (upamahanagar); 276 municipalities (nagar); 460 rural (goan) municipalities. The 75 former districts from east to west have been increased to 77 with ceremonial and minor coordinating roles. The 77 Chief District Officers (CDOs) continue to retain their administrative power as security and police are still under the Federal and CDO's control. And the 14 north-south zones and 5 development regions have become obsolete. Nepal has had 7 constitutions in 1948, 1951, 1959, 1962, 1990, 2007 and 2015.

2 AMSL (amsl) denotes height in meters from mean sea level. These altitudes are for hamlets where inhabitants live.

${ }^{3}$ In meteorology, "leeward and windward sides" are technical terms for the directional sides of a mountain. The windward side is that side which faces the prevailing wind (upwind), whereas the leeward, or "lee" side, is the side sheltered from the wind by the mountain's very elevation (downwind). 
weather patterns in the high mountains with its massive ramparts. It results in shaping unique micro "human living conditions", i.e., agriculture, livestock/transhumance or sale of labour for livelihoods and sustenance.

In terms of socio-economic mosaic, the communities are a mix of TibetoBurman speaking majority Tamang, followed by their "close-cousin" Ghale and Indo-Aryan Nepali speaking Dalit ${ }^{4}$. A majority of them are subsistence farmers and pastoralists and most of them have around six months or less food self-sufficiency. They are, thus extremely vulnerable to local weather patterns and vagaries of climate variability and change. It leads to a set of highly agile adaptation skills, to cope with the local peculiarities and environmental challenges, enabling them to cope and survive in the harsh high mountain surroundings.

Examining these high mountain communities, one finds a pattern of dominant gendered roles and responsibilities which are centered on, at least, seven major activities and these are:

- Livestock rearing/transhumance pastoralist,

\author{
- Agriculture, \\ - Eco-tourism, \\ - Labour within village, \\ - Internal and international labour/out-migration, \\ - Small trade/business, plus \\ - Services and employment within and outside the hamlets ${ }^{5}$.
}

The livelihoods activity for daily sustenance in upstream Rasuwa is dominated by livestock rearing followed by subsistence agriculture. The main livestock reared are yak, chauri, sheep, cow, goat and buffalo complemented by poultry chicken. The main crops grown are potato, maize, millet, barley, rye, beans, low land rice and mashur lentil (HIAWARE, 2016) ${ }^{6}$. Vegetables are becoming popular with support from NGOs and development projects. Other significant livelihood activities are ecotourism (home stay, handicraft, trekking guide, porters, vegetables, small shops); labour within and outside the village including providing labour or services to over a dozen hydropower plants; small trade/business; handicrafts plus internal and international labour outmigration (Ibid \& ICIMOD, 2016) [8].

\begin{tabular}{|l|l|l|l|l|}
\hline Characteristics & Gatlang & Goljung & Chilime & Remark \\
\hline Number of households & $\begin{array}{l}400(513)^{*} \\
\text { Tamang } \\
\text { Ghale } \\
\text { Dalits }\end{array}$ & $\begin{array}{l}269 \\
\text { Tamang } \\
\text { Ghale } \\
\text { Dalits }\end{array}$ & $\begin{array}{l}340 \\
\text { Tamang } \\
\text { Ghale } \\
\text { Dalits }\end{array}$ & $\begin{array}{l}\text { *Increased after the earthquake due } \\
\text { to family fragmentation }\end{array}$ \\
\hline Average landholding size & 12 ropanis & 12 ropanis & $\begin{array}{l}\text { A ropani is 74 feet times 74 feet and } \\
\text { most of the lands are bari land? }\end{array}$ \\
\hline Main income sources & $\begin{array}{l}\text { Agriculture } \\
\text { Livestock } \\
\text { Tourist services } \\
\text { Remittances } \\
\text { Employment }\end{array}$ & $\begin{array}{l}\text { Agriculture } \\
\text { Livestock } \\
\text { Tourist services } \\
\text { Remittances }\end{array}$ & $\begin{array}{l}\text { Agriculture } \\
\text { Tourist services } \\
\text { Local labor and } \\
\text { employment in } \\
\text { hydro power, }\end{array}$ & \\
\hline
\end{tabular}

\begin{abstract}
${ }^{4}$ The Tamang and Ghale are akin to one another and speak similar Tibeto-Burman or "Mongolian" language. The Dalit on the other hand speak Nepali and are Indo-Aryan group with specialization in various rural skills, i.e., iron smithy, leather works, tailoring, jewelry and other highly essential occupation skills. Traditionally shunned, discriminated and considered "untouchable" by the "sacred thread wearing" (tagadhari) high caste mainstream Brahmin/Chhetri Indo-Aryan groups. The Dalit as a group is therefore, highly discriminated and marginalized in Nepali village society. Currently, the Dalit group is recognized by the New Federal Democratic Constitution of Nepal 2016, as a caste group equal in the eyes of law. Despite this legal provisions and proactive discrimination including progressive steps in legal framework to include Dalit, Tamang and Ghale in mainstream Nepali political and socio-economic life - considerable psychological and pragmatic practices including historical prejudices prevail - which prevent them from taking substantive participation freely and equally in mainstream societal life, in par with other privileged advanced caste and ethnic groups such as Brahman/Chhetri and Adivasi Janajati. These deep seated socioanthropological subtleties and practices have substantial influences on the subject of this research based on "patriarchy", including division of labour, gender gap, gendered practices, access to benefits, access to institutions and, therefore, their "human conditions" in the high mountain.
\end{abstract}

${ }^{5}$ In future, a more rigorous quantitative "econometric" analysis can be undertaken on the "ever-changing" coping strategies of these mountain communities to ascertain the dominance of their time/task allocation in these livelihoods sector versus the monetary benefits/returns that they accrue to ensure their daily and periodic/annual livelihood needs. In a study of time/task allocation on the Status of Women in Nepal, (Shtrii Shakti, 2015); women's division of labour had changed substantially from a dominant agriculture and livestock management 30 years ago to agriculture, livestock management, labour, services and small business/trade more proportionately over these years.

${ }^{6}$ A Study on Socioeconomic Conditions and Drivers leading to Vulnerabilities in Upstream of Gandaki Basin: Acase of Rasuwa District, HI-AWARE, ICIMOD/SEARCH Nepal.

${ }^{7}$ Productive agricultural land in rural Nepal are divided into Khet land, Bari Land and Kharbari land which denotes irrigable wet land suitable for rice farming; rain-fed dry land which may or may not be suitable for rice cultivation with irrigation; and pasture or fodder suitable land. 


\begin{tabular}{|c|c|c|c|c|}
\hline & $\begin{array}{l}\text { in local cheese } \\
\text { factory, } \\
\text { benefit from } \\
\text { shares in HP }\end{array}$ & $\begin{array}{l}\text { Handcrafts, } \\
\text { benefit from } \\
\text { shares in HP }\end{array}$ & $\begin{array}{l}\text { benefit from } \\
\text { shares in HP }\end{array}$ & \\
\hline $\begin{array}{l}\% \text { households with out- } \\
\text { migrants }\end{array}$ & $50-55 \%$ & $15-20 \%$ & $15 \%$ & $\begin{array}{l}\text { Out-migration started from } 1990 \\
\text { onwards }\end{array}$ \\
\hline
\end{tabular}

(Source: Focus Group Discussions (FGDs), June 2017 in Upstream Rasuwa, HI-AWARE ICIMOD/SEARCH-Nepal)

Table 2: Socioeconomic Characteristics of Case Study Sites

The main income-generating items are milk from yak and cereal crops in these villages, i.e., potato, barley and local species of beans. Farmers reported that on average, each household sells 40 bags of potato $(50 \mathrm{~kg} / \mathrm{bag})$ every year, thus, making this cash crop an important source of income. Fresh green vegetables are grown currently for consumption and sale, as a result of opening-up of roads and efforts of development projects including nongovernmental organizations or NGOs (HI-AWARE, 2016 Socio-economic vulnerabilities and high Mountain agriculture field studies).

\begin{tabular}{|c|c|c|c|}
\hline Characteristics & Gatlang & Goljung & Chilime \\
\hline Main food crops & $\begin{array}{l}\text { Local maize, millets, } \\
\text { buckwheat, local beans }\end{array}$ & $\begin{array}{l}\text { Rice, lentils, soybean, other } \\
\text { local bean, potato }\end{array}$ & $\begin{array}{l}\text { Rice, beans, barley, millets, } \\
\text { potato }\end{array}$ \\
\hline Main cash crops & Potato, barley and beans & $\begin{array}{l}\text { Potato, lentils, mustard, } \\
\text { linseed }\end{array}$ & $\begin{array}{c}\text { Rice, potato, black lentils, } \\
\text { vegetables }{ }^{8} \text {. }\end{array}$ \\
\hline Main livestock & $\begin{array}{l}\text { Chauri }^{9} \text {, yak, goat, local } \\
\text { poultry }\end{array}$ & $\begin{array}{l}\text { Goat, cattle, buffalo, sheep, } \\
\text { local poultry }\end{array}$ & $\begin{array}{l}\text { Goat, cattle, buffalo, sheep, } \\
\text { Chauri, yak }\end{array}$ \\
\hline $\begin{array}{l}\text { Markets for agricultural } \\
\text { products }\end{array}$ & $\begin{array}{c}\text { Chilime, Saybrubesi, } \\
\text { Dunche } \\
\text { Kathmandu }\end{array}$ & $\begin{array}{l}\text { Chlime, Saybrubesi, } \\
\text { Dunche }\end{array}$ & $\begin{array}{l}\text { Chlime, Saybrubesi, } \\
\text { Dunche }\end{array}$ \\
\hline
\end{tabular}

(Source: Focus Group Discussions (FGDs), June 2017 in Upstream Rasuwa, HI-AWARE ICIMOD/SEARCH Nepal)

Table 3: Agriculture and Livestock

\section{The dominant task between women and men in Transhumance}

The communities in upstream Rasuwa are generally a peasant society. They are, thus, dependent on subsistence agriculture and highland livestock raising including transhumance pastoralism to ensure subsistence livelihoods. The time and task activities for women and men are centered around the above two areas, However, in the recent past decades, service; intra-international labour; petty trade; trekking tourism; home-stay and services in hydro-power plants have supplemented their income, employment and livelihoods coping strategies.

The results of the FGDs above illustrate that women carry out most of the task related to agricultural production at the household $(\mathrm{HH})$ level. In most cases, women carry out 5-8 major activities in agriculture compared to two or three for men. Furthermore, 3-4 activities are carried out by both women and men thus making women the overwhelming carriers of agricultural burden, clearly illustrating the feminization of agriculture. In terms of hours of work, women also provide more daily labour and drudgery over men in these hamlets. Rigorous quantitative time/task allocation studies (TAS), elsewhere; demonstrate that women outperform men by nearly 3.5 hours more than men on daily average bases on similar conditions and circumstances (The SOWN Study, 2015) ${ }^{10}$.

Outmigration of able bodied young men and some women from these hamlets also mean - that in the case of women left in the $\mathrm{HH}$ - as spouse of tourist guides and trekking trade men; transhumance herders and migrant labourers; women perform and carry out almost all of the agricultural activities including ploughing and hoeing the fields ${ }^{11}$. The benefits are often shared in the family with women making substantial sacrifices for family welfare, nurturing and sustenance. The real incentives for women to work hard and carry the triple burden of productive, reproductive, social and civic responsibilities are to provide for family's livelihood needs and to nurture and care for children and elderly in the households - in the hope that her family's quality of life improves in the subsequent generations to follow. In a patriarchal mountain community, women bear these extra work-burdens stoically, with aplomb, despite discriminations and sacrifices inherently involved in such unequal gender relationships.

One finds women carrying out almost all activities in the agricultural production chain, i.e., seed selection; buying seeds; sowing; manureing; planting; weeding; harvesting and storing; except notably, marketing which is an economic/marketing activity. In comparison, men carry out heavier labour intensive polughing and economically crucial buying; selling and market related activities. This marketing activity provides them more choices and opportunities in the household economy economy and decision making functions over women. There are some exceptions as well; where in the case of cash-crop Chiraito (Swertia chirayita) growing, women farmers from Tetangche hamlet, Chilime; men-folks and spouses are sharing the work burden equitably with women. Likewise, Ghale women from Goljung are demonstrating their ability to buy/sell and

${ }^{8}$ Vegetables grown commercially of later are cabbage, radish, carrot, cucumber, chili, tomato, cauliflower, onion, garlic and spinach.

${ }^{9}$ A cross between a male yak (Bos grunniens) and a cow (Bos indicus) is called a chauri gai. Chauri is a hybrid female which produces more milk and is preferred. The male from this cross is called a jopo (djo) and the chauri is called a djimo. The jopo is not fertile. There are many variations of hybridization of yak and cattle, but the most popular is the chauri among the transhumance herders of Rasuwa.

${ }^{10}$ Revisiting the Status of Women in Nepal, SOWN, Shtrii Shakti, 2015.

${ }^{11}$ Ploughing and hoeing or land preparation are normally done by men in Nepal across socio-economic, caste and class division. 
market their product in the absence of men. Similarly, the responsibilities for entrepreneurial women who are running small business, shops, and home-stay are challenging as they have to run the household economy with "triple-burdens" as well as their micro-enterprises ${ }^{12}$.

Dalit women cope with their household economy challenges through rearing small livestock, i.e., cattle, goat and poultry ${ }^{13}$. Dalit men supplement their spouses' effort through manufacturing agricultural tools for barter or trade with the villagers. Women whose spouses are away as migrant workers carry out all agricultural activities. Similarly, women whose spouses are in the rangelands or kharkhas for 5-6 months in a year, face the added burden of running the household economy, plus providing logistical support, nearly every fortnight or monthly buy supplying men with ration of food, clothing and essential supplies for men and their animals - thus, severely stretching their ability to survive in an harsh environment ${ }^{14}$. Men, on the other hand, respond to the challenges of the household economy for food security, income generation, employment and livelihoods by working as labourers, masons, builders, carpenters, porters, tourist guides, labourers/service providers in hydropower projects, petty services or migrate further afield to urban towns and international labour market in the middle-east Gulf or south east Asian countries.

\section{Activity, Benefit and Incentive in Livestock Rearing}

The results of the FGDs on the "Activity, Benefit and Incentive in Livestock Rearing"; together with "Activity, Benefit and Incentive in Agriculture"; reinforces the widely held belief and theory of the "insideoutside" dichotomy on gender roles within rural agrarian household economy. In this theory, women perform most of the task and drudgery inside the household and the farm-economy. In contrast, it is the men who interact with the outside world. This is due to the fact that men are more mobile, better informed, more formally educated and more confident, able and adept in dealing with the "outside word" of markets and institutions away from home, hearth and the farmstead.

The women in most of the villages undertake fodder collection, feeding animals, cleaning sheds, managing and caring for the animals and birds, milking and providing traditional first-aid. In contrast, it is the men-folks who do the buying/selling and marketing of products from animals and birds. There are subtle differentiations as well - in livestock rearing/management and agricultural activities - among various socioeconomic categories as noted in Table 4 and 5 above. In the case of micro-entrepreneur women's group, i.e., cash-crop growers, small business owners, home-stay managers; women cope by paying labor to supplement their livestock and agricultural work. However, due to substantial labour migrations from the villages, women have to pay for hired farm labour to perform their own household tasks related to livestock management and agricultural work. Shortages of farm labourers in the household economy is also leading to breaking the "glass ceiling" on buying, selling and marketing of livestock products. This is because women have to come forward to undertake these activities in the absence of men especially with categories under migrant labourers and transhumance herders - who are away for extended period of time in a year.

What is from the FGDs with women and men of upstream Rasuwa is that prized grasslands (rangeland) called kharka, i.e., Sanjen Kharka, between northern Rasuwa and Tibet - is contested and fought for grass-fodder for yak, chauri, sheep and goats - among the villagers. The change in climate and rise in temperature has had adverse effect on the transhumance

${ }^{12}$ Women in the household economy typically undertake and accomplish what is called the triple burden of productive, reproductive and the social roles.

${ }^{13} \mathrm{HH}$ equals household or households in short. pastoralist in terms of access, control and benefits from such rangelands. The group reported that there is less pasture land by area for all the 50 plus Goths. More families are resorting to keeping Goths in the rangelands. Water sources are drying up and the quality of grasses are deteriorating due to less and infrequent rain and moisture. The rangelands
${ }^{14}$ Sangjen Kharka (Rangeland/ meadows at over 4,500 m bordering Tibet and Rasuwa) reportedly has 200 Goth or nomads caravan settlement each with over 100 big and medium animals such as yak, chauri and sheep. 
are also becoming scarcer due to internal and international political control between Nepal and the Tibet Autonomous Region (TAR $)^{15}$.

The younger generation and youth have benefited, to some extent, from the globalization, development of markets, employment opportunities, eco-tourism and more choices offered by contemporary modern lifestyles than their forebears. However, migration to towns and cities and less harsher life for livelihoods preferred by young couples and youth are also posing challenges to these hamlets. Generally speaking, there are very few youth taking up transhumance herding in upstream Rasuwa.

\begin{tabular}{|l|l|l|l|}
\hline Domestic Animals & Gatlang & Goljung & Chilime \\
\hline Main livestock & Yak, chauri ${ }^{16}$, goat & Goat, cattle, buffalo, sheep & $\begin{array}{l}\text { Goat, cattle, buffalo, sheep, } \\
\text { Chauri, yak }\end{array}$ \\
\hline
\end{tabular}

(Source: Focus Group Discussions (FGDs), June 2017 in Upstream Rasuwa, HI-AWARE ICIMOD/SEARCH Nepal)
The increase in foot and mouth disease on Yak and ruminant livestock

The main livestock population of Gatlang, Goljung, Chilime including other adjoining villages, i.e., Thuman, Briddhim and Syabru are yak, chauri, buffalo, cow, ox, sheep and goat. The bovine cattle populations are confined to villages in lower altitudes, whereas yak, chauri, goat and sheep are grazed in higher mountain rangelands.

Table 4: Main Livestock Population

Due to climate change, temperatures are rising dramatically in higher mountains annually. Weather variability is affecting less humidity, dryness and moisture loss in the air and surface environment. The practice of transhumance in these communities means that livestock are grazed in upstream and downstream environment during summer and winter depending on availability of grass and fodder. The prevalence of 'foot and mouth' (FMD) disease in almost endemic and 'pandemic' proportion in sub-tropical conditions of Nepal has led to livestock population vulnerable to this disease ${ }^{17}$. Furthermore, it has also led to dangers and vulnerability of contracting 'hand, foot and mouth' (HFMD) disease for the human population in these highland villages and rangeland ${ }^{18}$.

The animal health extension in the upstream Rasuwa is non-existent, resulting in herders administering a number of local medications based on their culture and indigenous knowledge. One common remedy is to take the infected livestock to higher pastures above 2-3,000 meters. The other common oral recipe is to feed the animals with a mixture of protein rich diet such as eggs, honey and edible camphor including herbs and medicinal plants found in the meadows.

The ill-effects of this disease are multifarious on both animals and human herders. The yak, chauri and ruminants produce less milk. The male

15 Historically customary laws governed the contagious areas of rangeland where pastoralist could graze their animals in the northern and southern meadows of Tibet and Nepal. In contemporary geopolitical scenario, administrative and political boundaries have changed and are more structured, thus depriving pastoralists from Nepal to take benefits from grasslands in Tibetan frontiers.

${ }^{16}$ A cross between a male yak (Bos grunniens) and a cow (Bos indicus) is called a chauri gai. Chauri is a hybrid female which produces more milk and is preferred. The male from this cross is called a jopo (djo) and the chauri is called a djimo. The jopo is not fertile. There are many variations of hybridization of yak and cattle, but the most popular is the chauri among the transhumance herders of Rasuwa.

17 Foot-and-mouth disease or hoof-and-mouth disease (Aphthae epizooticae) is an infectious and sometimes fatal viral disease that affects cloven-hoofed animals, including domestic and wild bovids.[1][2] The virus causes a high fever for approximately two to six days, followed by blisters inside species become impotent and cannot produce off-springs. The draft animal, especially, chauri cannot carry heavy burden of timber or local goods. In extreme cases they become ill and dormant and suffer fatalities. These ill-effects in turn causes the family members of herders to earn less from milk, meat and animal products. This causes them to become poorer and impoverished. Eventually, such a negative economic impact leads the transhumance herders to become indebted to village money lenders. In extreme cases they abandon their livestock transhumance trade and become 'environmental and economic' refugees in towns and cities. They eke out a miserable living and the family members suffer from debt, disease, insecurity and vulnerability from "human traffickers" and "loan sharks" in small towns or bigger cities. Women and young girls are often the victims and major sufferers in this vicious cycle.

\section{Customary Institutions and Governance system}

The traditional customary governance systems based on the "council of elders" like in many Asiatic societies, have been a strong local institution for traditional governance in upstream Rasuwa. Locally it is called the Chogo system and each year up to two Chogos or headmen are chosen as leaders of the community. This is usually during the month of May or June each year, when a ten day long festival of Mani Rimdu or mini-Losar is celebrated during the birth of Lord Buddha. ${ }^{19}$

the mouth and on the feet that may rupture and cause lameness (see Wikipedia).

18 Hand, foot, and mouth disease (HFMD) is a common infection caused by a group of viruses. It typically begins with a fever and feeling generally unwell. The viruses that cause HFMD are spread through close personal contact, through the air from coughing, and the feces of an infected person.8] Contaminated objects can also spread the disease.[8] Coxsackievirus A16 is the most common cause and Enterovirus 71 is the second-most common cause.[6] (See Wikipedia).

${ }^{19}$ Losar or Locchar, meaning the New Year, is usually celebrated during the full month of winter following the lunar calendar. It falls between January/February each year depending on the lunar cycle. The Tamangs celebrate the Sonam (common people) Losar which comes a month or a fortnight earlier than Gyalpo (nobility) Losar which at times coincides with the Chinese New Year. Mani Rimdu festival is celebrated as the mini Losar during the middle of the year. This is the occasion when a Chogo/Chogos are elected 
The Chogos oversee a number of important functions such as natural resources management, conflict mediation, social and religious affairs, mediation of development works between communities and district authorities etc. The Chogo system, which is an informal governance system, is particularly strong and active in Gatlang village compared to Goljung or Chilime where the system exists only notionally.

This customary system has been held in great respect by the local people of upstream Rasuwa. The system has substantial influence over the lives and ability of the people to cope with everyday existence from agriculture, livestock management, transhumance, and rangeland management, conflict mediation to social mores, religious norms and values of the communities in the three research sites.

The formal/statutory government system has recognized the importance of the Chogo system and has been allocating financial budgets for the remuneration of the Chogos in Gatlang since the last few years. Every individual has access to and benefit from this customary governance system including the minority Dalits in these three hamlets. However, it is a "patriarchal system" and the representation of women and her substantive participation in the position of the institution of the Chogo has remained minimal. It has always been a male domain. Despite this drawback, the benefits and position of women have been assured in this customary governance system. In the ever changing formal and unpredictable political system in Nepal, this informal system has substantial part to play and contribute to resilience against the vagaries of climate change and variability in the future. This is very relevant in a geographical location, i.e., highland meadows and rangeland, where formal government system of governance is yet to make its presence felt. The customary system is also inclusive and is close to the grassroots to consider the plights and aspirations of minorities such as women, Dalits, youth, children, girls and people living with disabilities (PLWD) and senior citizens.

\section{Transhumance Herders (Men stay in pasture lands and women provide logistic support)}

The women members of the transhumance herders manage their livelihoods need by intensely cultivating their small-plot farms with potatoes, corn, rajma-beans, black lentils, sesame seed and millet. They are also turning to cash crop farming with green leafy vegetables and tomatoes, thus, supplementing their income by keeping cattle, sheep, goats and chickens. Most of the management responsibilities are shouldered by women of the households. Men take yak, chauri, sheep and cattle and stay at least 6 months in pastureland, in order to supplement household income through herding animals, producing cheese and processing milk and milk products. They sell milk to the cheese factory and also sell animals to the villagers. A hard cheese called churpi is sold as traditional edible product. Another variety is exported as canine food to animal lovers in places such as the United States of America and Europe.

Support and benefits from the non-state informal system, i.e. the Chogo system or the system of traditional governance (ghedung) by the elders, have been the customary governance systems and source of ancient institution in the three case study hamlets. The community members have benefited from this system, which continues to this day, most actively in Gatlang. In this system, the two male Chogos dispense and govern the community land rangeland, forest, water and other natural resources. The Chogos also help in conflict mediation and preside over cultural and religious affairs and festivals of the community members. Women, men

by consensus in hamlets of upstream Rasuwa. The Chogo system is particularly vibrant in Gatlang hamlet to this day. and Dalits have benefitted from this system equitably. The local government in recent years has been subsiding the remuneration of the Chogos, realigning its values and strategically harmonizing the loyalty of the local governance system with state policies and programmes in highland Rasuwa.

It is on note to mention here that the informal "kith and kin" system of family self-help groups and clan support, has been vital for the coping strategies of these communities ${ }^{20}$. Women and men (and women in particular who have little formal control over land or physical asset like house) rely on this system of "active mutual support" from close relatives and "clan network" to survive in a challenging and at times harsh "human condition" and environment in highland Rasuwa. Access to finance and loans (A2F), in times of dire needs for the individual and families are also met through informal system of "money lenders". The "money lenders" are normally relatives who can trust other relatives who are provided loans based on the "promise" of payback and clan trust. On the face value, it appear "usurious", as such informal and risky loans are as high as 100 (\%) interest rate within 2 years' time. Despite this stiff rent, and in the absence of alternatives, women and men in need do take such "family loans" for investment, health care, education, building house or for expenses required during migration to third countries in search of jobs and better income.

Noting that the economic conditions in high mountain communities is dire, in the best of times and extremely harsh during unpredictable climate variability, the traditional governance and customary institutions have important role to play in order to ward of vulnerability from external shocks such as foot and mouth (FMD) disease. It is, therefore, prudent that the 'Centre' represented by the newly introduced federal democratic governance system in Nepal from 2016 as an outcome of the 2015 Constitution consider the comparative advantage of local institutions and support it fully to improve rangeland management, provide veterinary extension support through these systems and ensure that fatal disease such as (FMD), bird-flu or other zoonotic disease are dealt with on routine basis with vigilance and early advance warning system. Currently, with pandemic such as COVID-19 also being detected in the region, the case for careful vigilance and preventive measures through the customary governance system is a sine quo none condition.

\section{Overall Adaptation and Sustainable Livelihoods Strategies}

Human beings like their wildlife counterparts, tend to confront, hibernate or migrate as adaptive measure to overcome climate change stressors. The "adaptation" or "confrontation" to climate change in highland Rasuwa, has been to intensify agricultural cropping patterns and to move towards cash crop cultivation. At the same time livestock management and transhumance herding have been intensified twice over. The gathering of non-timber forest products (NTFPs), farming of rainbow trout fish, trekking tourism, home-stays, setting up restaurants, shops, small business and trade have been intensified. Furthermore, in order to supplement household income, each of the family has sent at least one member to towns, cities or third countries in order to earn extra income and supplement the house hold economy and bolster sustainable livelihoods.

\section{The Institutional mechanism of the Traditional Customary Headman system}

In the transhumance pastureland management, the Chogo is "mandated" to oversee the local rangelands. He is, therefore, effectively in-charge of

20 The Tamang people originated with 18 "golden clans" initially and currently have over100 sub-clans based on locations and geography (Dr. Mukta Singh Lama) 
the communal pasture-land in highland land meadows called kharkas. The accountability of the Chogos is ensured through a council of elders much like the Loya Jirga in northern Pakistan and Afghanistan. Each village or conglomeration of hamlets chooses it representative called the "Ditta". The Dittas are "mandated" by the council of elders to oversee the leadership and management role of the Chogos.

The traditional Tamang "customary law" is based on traditional rules of the game or the code of conduct $(\mathrm{CoC})$ called the rimtim or cultural propriety of the community. These are based on trust and honor. The rimtim is strong and most of the community members adhere and follow the $\mathrm{CoC}$ or face its consequences such as the risk of "ostracization" and isolation by the community and clan members. The position of the elders in the society including ancestors and parents are also respected by the community members. The Goompa and the Lama play an important role. Besides these traditional institutions, there are two "mani jatras"; similar to a one day long "mani Rimdu" or prayer sessions during Buddha Jayanti around mid-May. This is during the fortnight long reading of the sacred text or sutras called "domang" or "kangur" recitation sessions. After such ceremonies, the wild spirit or ghost "mahmo" is warded-off from the villages and the community members - much like stoning of the devil in Mecca. These traditional religious and spiritual celebrations, including days or week-long reading of the sacred scriptures, are followed by more utilitarian secular business such as administration of the village and community life. These include managing common property and natural resources in a sustained and pragmatic manner.

In similar vein, when it comes to agro-forestry and agricultural cultivation practices, the governance system is defined and determined by the traditional customary law. This is normally defined by the hierarchy based "religious order" such as existing Lamas in olden times. In the current contemporary times, the Lama themselves do not come forward as "Ditthas" but select or nominate their "proxy" to become the "Ditthas".

The Ditthas are constituted out of the local religious orders, civic society members and members of the political parties. They become like the "constitutional councils" in order to have oversight of the Chogos and ensure community accountability.
In terms of the natural resources management, Chogos carry out the supervisory function. They are closely and informally guided and "monitored" by the Ditthas. A person wishing to make use of the resources of the rangeland - which is usually in small manageable areas like 30-50 chauri load of grasses for each individual family - approaches the Chogos and the Ditthas with financial and material offers in an informal auction or bid process. In traditional terms, these bids are called the "pong" and "salgar". The process of approaching the traditional customary authority is called the "pong" and the material or financial offer the "salgar". Once there is an agreement between the Chogos and the concerned person, then s/he can harvest or extract the natural resources such as grass, fuel or timber according to volume for a year or one season and/or graze the yak, chauri and sheep. The natural resources can be also timber and fuel-wood harvest. In fact, the value placed on good grass land is such, that one arranges one's daughter's marriage based on the green pasture and good grass possessed by the groom in his hamlet.

Remuneration of the Chogos was conventionally paid "in-kind" or in "cash" by having specific amount of grains, butter or ghee allocated to a Chogo. Currently, in order to compensate the Chogos leadership, a monthly remuneration of NRs. 6,000 each month is allocated by the Local Government.

Reportedly, there were around 50 Goths in Sanghen Kharka in 2017. Livestock such as chauri, yak, goat and local poultry (Table 3) are important sources of food and income for households in the highland mountains. Chauri is the most important livestock for this high-altitude area because of its resilience towards severe cold and in times of fodder stress. Households have constructed 50 small shelters for chauri and yak herds in the high-altitude areas of the rangeland, where at least 50 male members of households stay to take care of livestock. They bring chauri/yaks to the nearby Sangen pasture for grazing. (Sangen is a big pastureland that extends to Tibet and is shared by Gatlang, Goljung and Grey settlements inter alia). This is one reason why women must carry out agricultural work in the absence of men. During the winter months, snow covers the pasture land, and households use dried crop residues as fodder for livestock. Chauris are a good source of income for households (See Box 1 below) ${ }^{21}$.

The Dairy Development Corporation (DDC) of Nepal established a cheese factory in Gatlang in 1977 (2,600m above mean sea
level). This factory is still operating and providing good income opportunity to local livestock farmers. The factory produces
$9,000-11,000 \mathrm{~kg}$ of cheese and $3,000 \mathrm{~kg}$ of butter each year. This requires the supply of nearly 90,000 liters of milk annually
from Gatlang livestock farmers. Farmers are not only meeting this milk demand but also save sufficient milk for family
consumption. The price of milk is determined by the factory based on the fat contents in the milk. On average, Nepali Rs. $54 /$ liter
(US\$ 0.51) is being paid to milk suppliers. Overall, 40 chauri farmers supply 246 litres of milk per day to the factory And each
household's annual gross income from milk sale is nearly Rs. 121,500 (US\$ 1,146). It implies that the 40 chauri farmers earn
nearly Rs. 10,000 (US $\$ 94$ ) each month from the sale of chauri milk. Distributions of gross milk income across all 400
households reveal an average income of nearly Rs. 12,000 (US\$ 113) month. This is a good complementary income to each
family of transhumance yak herder.
Box 1 Income from Sale of Chauri Milk in Gatlang

\section{Conclusion}

Climate Change has resulted in unprecedented altering of established weather patterns, precipitations, snowfall, rain, soil moisture, humidity, wind, fog, and temperature. It has altered century old weather patterns and seasons ushering more hot and warm weather in the mountains. With these changes, there have been marked and visible increase in disease patterns in animal, wildlife, plants and human populations of the high altitude Himalayan hamlets in Nepal. This has led the ruminant animal populations such as yak, chauri, sheep and got to become susceptible to fungal, bacterial, viral and other commonly and easily communicable zoonotic disease such as "foot and mouth disease (FMD)" in animals and dangers of "hand, food and mouth disease (HFMD)" in herders and household members of the community. These external shocks have severely impacted the coping strategies and earning capacity of transhumance herders of upper Rasuwa. It has had negative impact on their family and community leading to degradation of
21 Interviews with Key Information Persons (KIP) Mr. Jeevan Lama Syangten, Gatlang, Rasuwa and his father Mr. Kesang
Wangdi Tamang including transhumance herders of Sangen Kharka, Dandagoan, Thulogoan, and Sharamthali rangelands. 
heir quality of life and human development index such as health, nutrition, education, upward mobility and general well-being. The burden has been most severely felt by single women, women heads households, young children, pregnant and lactating mothers, unborn children and youth.

The phenomenon of climate change and weather variability has ushered uncertainty, change and diversification in the coping strategies. In comparison to a few decades ago, occupational tasks have diversified from agriculture and livestock management to unskilled labour services, service in eco-tourism; working in trekking tourism as guides and porters; running home-stays and lodges, collecting and selling NTFPs (non-timber forest products) and working in development projects such as roads and hydropower plants. In the past decades, there has been marked increase in international and international labour migration in order to support income for household expenses.

As these diversifications in time, task, risks and occupations take place; one also sees that communities have become more vulnerable to the vagaries of climate change including globalization, penetration of commodities from third countries and impoverishment of the highland community members. The pandemic in the form of COVID-19 has meant further shock to the transhumance herders and their relatives. This is because labour opportunities have disappeared abroad and the danger of falling ill due to communicable disease have increased. The formal governmental institutions such as health posts, veterinary posts, forest range posts and banks are yet to make an impact in these remote areas due to remoteness and "political will" to operate in difficult conditions. In their absence, it is the "informal system" of clans, kins and close family members, who provide support to one another in times of needs and wants, such as during the Pandemic and increase in communicable diseases such as FMD and HFMD.

The government of Nepal and the Local Governments (LGs) can and should work with the transhumance herders, local communities and their leaders to improve the knowledge, skills, attitude and coping strategies. Noting the lacuna in the formal institutions of the government and building on the strength of the millennia old customary systems of the Chogos and the indigenous knowledge systems, the LGs can provide useful help and support to the local community of upper Rasuwa who can continue their tradition way of life through transhumance. It will continue to complement their coping mechanism and additional wealth generation opportunities to sustain their well-being.

\section{References}

1. Asha Hans, Nitya Rao, Anjal Prakash, Amrita Patel, Edited: Engendering Climate Change: Learnings from South Asia. 3 March 2021, London, Routledge.

2. Campbell, B. (2017). Encountering climate change: Dialogues of human and nonhuman relationships within Tamang moral ecology and climate policy discourses, European Bulletin of Himalayan Research, 49: 59-87.

3. Campbell, B. (1997). The heavy loads of Tamang identity.' In David N. Gellner, Joanna Pfaff-Czarnecka and John Welpton (eds) Nationalism and Ethnicity in a Hindu Kingdom. The Politics of Culture in Contemporary Nepal. Abingdon: Routledge: 205236.

4. CBS. (2013). Summary of National Agriculture Census (2011) AD (2068BS), 2013. Kathmandu: Central Bureau of Statistics. Climate change, gendered vulnerabilities and resilience 123

5. Dandekhya, S., England, M., Ghate, R., Goodrich, C.G., Nepal, S., et al. (2017). The Gandaki Basin: Maintaining Livelihoods in the Face of Landslides, Floods, and Drought. HI-AWARE working paper 9. Kathmandu: ICIMOD.

6. Gerlitz, J.Y., Hoermann, B., and Hunzai, K. (2011). Understanding Mountain Poverty in the Hindu Kush-Himalayas:
Regional Report for Afghanistan, Bangladesh, Bhutan, China, India, Myanmar, Nepal, and Pakistan. Case Study. Kathmandu: IFAD.

7. Gilson, E. (2013). The Ethics of Vulnerability: A Feminist Analysis of Social Life and Practice. New York: Routledge.

8. Goodrich, C.G., Mehta, M., and Bist, S. (2017). Status of Gender, Vulnerabilities and Adaptation to Climate Change in Hindu Kush Himalaya: Impacts and Implications for Livelihoods and Sustainable Mountain Development. ICIMOD Working Paper 2017/3, International Centre for Integrated Mountain Development, Kathmandu.

9. Goodrich, C.G., Prakash, A., and Udas, P.B. (2019a). Gendered vulnerability and adaptation in Hindu-Kush Himalayas: Research insights, Environmental Development, 31: 1-8.

10. Goodrich, C.G., Udas, P.B., and Larrington-Spencer, H. (2019b). Conceptualizing gendered vulnerability to climate change in the Hindu Kush Himalaya: Contextual conditions and drivers of change, Environmental Development, 31: 9-18.

11. Gurung, D.R., Maharjan, S.B., Shrestha, A.B., Shrestha, M.S., Bajracharya, S.R., and Murthy, M.S.R. (2017). Climate and topographic controls on snow cover dynamics in the Hindu Kush Himalaya, International Journal of Climatology, 37: 3873-3882.

12. Harding, S. (1986). The Science Question in Feminism. Ithaca, USA and London, UK: Cornell University Press. HI-AWARE. 2017. 'Socio-economic Assessment Report - Gandaki River Basin, Nepal.' Himalayan Water and Resilience Research (HIAWARE) International Centre for Integrated Mountain Development (ICIMOD), unpublished report.

13. Humagain, K., and Shrestha, K.K. (2009). 'Medicinal plants in Rasuwa district, central Nepal: trade and livelihood', Botanica Orientalis: Journal of Plant Science, 6: 39-46. IPCC. 2014.

14. 'Climate Change (2014): Synthesis Report. Contribution of Working Groups I, II and III to the Fifth Assessment Report of the Intergovernmental Panel on Climate Change' (Core Writing Team, R.K. Pachauri and L.A. Meyer (eds). Geneva:

15. IPCC: 151. Khan, A., Cundill Kemp, G., Currie-Alder, B., and Leone, M. (2018). 'Responding to Uneven Vulnerabilities: A Synthesis of Emerging Insights from Climate Change Hotspots'. CARIAA Working Paper no. 22. International Development Research Centre, Ottawa, Canada and UK Aid, London, United Kingdom. Available online at: https://idl-bncidrc.dspacedirect.org/handle/10625/56958

16. Koirala, M., Udas, P.B., and Goodrich, C.G. (2017). Gender and social inclusion in environmental discourse. In D. R. Bhuju, M. Koirala and R. Nakarmi (eds), Environmental Science- Some Theoretical Background and Applications. Kathmandu: Central Department of Environmental Science, Tribhuvan University and International Centre for Integrated Mountain Development.

17. Lamichhane, A.P. (2005). 'Osteoporosis-an update'. Journal of the Nepal Medical Association, 44(158): 60-66. 124

18. Merrey, D.J., Hussain, A., Tamang, D.D., Thapa, B., and Prakash, A. (2018). 'Evolving high altitude livelihoods and climate change: A study from Rasuwa District, Nepal',

19. Food Security, 10(4):1055-1071. Nepal Gazette. (2018). Department of Printing, Ministry of Information and Communication, Government of Nepal

20. Pasteur, K. (2011). From Vulnerability to Resilience: A Framework for Analysis and Action to Build Community Resilience. Rugby: Practical Action Publishing.

21. Pradhan, R., and Shrestha, A. (2005). Ethnic and Caste Diversity: Implications for Development. Kathmandu: Asian Development Bank, Nepal Resident Mission.

22. Sharma, E., Molden, D., Rahman, A., Khatiwada, Y.R., Zhang, L., et al. (2019). Introduction to the Hindu Kush Himalaya 
Assessment.' In P. Wester, A. Mishra, A. Mukherji, A.B. Shrestha. (eds) The Hindu Kush Himalaya Assessment: Mountains, Climate Change, Sustainability and People. Berlin and Cham: Springer.

23. Shtrii Shakti. (2015). Revisiting the Status of Women in Nepal. Kathmandu: Shtrii Shakti.
24. Tamang, M.S., and Gurung, O. (2014). Social Inclusion Atlas of Nepal, Ethnic and Caste Groups (Vol. 1). Central Department of Sociology/Anthropology, Tribhuvan University, Kathmandu, Nepal.
Ready to submit your research? Choose Auctores and benefit from:

$>$ fast, convenient online submission

$>$ rigorous peer review by experienced research in your field

$>$ rapid publication on acceptance

$>$ authors retain copyrights

$>$ unique DOI for all articles

$>$ immediate, unrestricted online access

At Auctores, research is always in progress.

Learn more https://auctoresonline.org/journals/biotechnology-andbioprocessing 